Journal of Engineering and Applied Sciences 15 (6): 1273-1288, 2020

ISSN: 1816-949X

(C) Medwell Journals, 2020

\title{
Spatial Integration and Urban Aglomeration in the Mamminasata Metropolitan Area
}

\author{
Batara Surya, Haeruddin Saleh and Syafri \\ Departement of Urban and Regional Planning, University of Bosowa, Makassar, Indonesia
}

\begin{abstract}
The rapid development observed in metropolitan cities affects the spatial interaction between regions and urban cluster settlements, leading to the fiscal growth of suburbs. This study is therefore, aimed to examine and analyze the spatial integration, urban agglomeration, economic growth and formation of the social territorial structures in the Mamminasata Metropolitan suburb using a combination of qualitative and quantitative approaches. Meanwhile, data were obtained through observation, surveys and documentation studies. Furthermore, the results showed that an elevation in the pattern of urban activities elicited changes parameters assessed which lead to economic growth in the suburbs of Mamminasata Metropolitan. This finding further indicated that spatial integration an urban agglomeration and the increase of activity, led to land tenure inequality and differences in adaptation between migrants and the local community. However, changes in spatial use influenced the structure and pattern of space, therefore, causing the formation of social territorial structures in the area.
\end{abstract}

Key words: Spatial integration, urban agglomeration, economic growth, suburbs, Mamminasata Metropolitan, integration, economic

\section{INTRODUCTION}

Globalization and urbanization are important aspects in the assessment and measurement of development and growth indicators in cities and metropolitan areas in Indonesia. This has brought a number of challenges to the fore, particularly those that require collaboration, innovation and capability development between nations (Oyinlola et al., 2018). Furthermore, a strategy for sustainable urbanization, especially, the land use policy has been implemented in some cities for years ( $\mathrm{Lu}$ and Ke, 2018). This has lead to economic growth, changes in spatial attributes and integration of urban activity systems and its relative dynamics are much higher than in the centres of the largest cities (Kowalczyka et al., 2019). Urbanization is a worldwide process which occurs rapidly, accompanied by adverse consequences on the environment and people (Hamma and Petrisor, 2018). Moreover, city planners and policy makers have an important role to play in tightening the village-to-city land conversion system and curbing expansions (Zhang et al., 2018). Furthermore, the growth of suburbs has an impact on the changes in the environmental ecology, economic productivity and land allocation for various activities which are the key points to optimize its functions and resource allocation (Wang et al., 2018).

Economic polarization and spatial propagation of centrifuges have led to the shift of productivity function in farmlands in the Mamminasata Metropolitan suburbs. This influences the changing spatial physical characteristics of rural agriculture, towards socio-economic activities. Therefore, preservation efforts must be present in the plans by focusing on two policy tools-prime which include farmland preservation and its conversion quotas (Zhong et al., 2018). The increase in developmental activities and conversion of productive agronomic lands as well as the strength of the fiscal linkage are influenced by distance, population explosion and growth of economic activities (Ye et al., 2019). Furthermore, urban land laws in the post-revolutionary era are considered as one of the most influential factors in the expansion of a city (Masoumi et al., 2018).

This shift in land use has changed the morphology and typology of Mamminasata Metropolitan suburbs, characterized by developmental complexity which is responsible for changes in the spatial structures and patterns both linearly and concentrically. However, regional land use morphology is altered adaptively with socio-economic developments which became the use transition at the appropriate time (Qu and Long, 2018). This influences urban expansion and development while structures should be seen from both physical and socioeconomic perspectives (Azhdari et al., 2018). Furthermore, economic growths lead to spatial integration in the Mamminasata Metropolitan suburbs which resulted in urban sprawl, characterized by several negative impacts on social, economic and environmental sustainability in the metropolitan area and the complexity of spatial use (Kovacs et al., 2019). The financial resources from the structural funds do not contribute to the occurrence of eliminating regional disparities, rather it strengthens their position towards the periphery (Matlovic et al., 2018).

Spatial integration is in line with changes in its use and is also capable of increasing the flow of transportation, due to socio-economic activities, industrialization and modernization which has led to 
mobility differentiation between external transit systems and that of the local communities in the suburbs of Mamminasata Metropolitan. Moreover, low and high socio-economic groups significantly differentiate the direction of their movements, adding up to the separation within and between settlements on the outskirts of the city (Kristof, 2018). Development oriented towards the center of fiscal growth (physically, economically and socially) positively influences spatial interaction, therefore, causing the formation of a system of municipal activities (Surya, 2015b). This reveals the interaction between migration and the level of development, therefore, suggesting the importance of geographic location, besides the socio-economic factors (Lukic and Stoilkovic, 2017). Hence, suburbanization of the Mamminasata Metropolitan area altered the way migrants and local communities responded to the change stimuli. However, suburbanization caused by economic agglomeration leads to the inability of local communities to access the reproductive resources in suburbs spaces (Surya et al., 2018a).

Urban clusters affected the formation of activity systems, due to the concentration of various socio-economic conducts, especially, those arising from market processes (Wang and Tomaney, 2019). The development of space allocated in the Mamminasata Metropolitan suburbs, characterized by the presence of large-scale settlements (116,976 ha), trade and service areas of 3,829 ha, education section of 31.33 ha and various social economic activities. Meanwhile, the intensity of growth was influenced by the low value of land in comparison with the city center and its use limitation. Furthermore, core metropolitan areas where land is scarce and its values are usually much higher than in peripheral areas (Mualam et al., 2019). These development dynamics is characterized by economic agglomeration which affects the grouping of urban activities, community segmentation and socio-economic segregation in the suburbs of Mamminasata Metropolitan. However, spatial discrimination has an enormous impact on poverty (Rochovska and Rusnakova, 2018) as the settlements possess complex social-economic problems (Balogh et al., 2018).

With reference to the several description above, the following considerations were assessed in this study the effect of increase in the pattern of urban activities on the utilization of the Mamminasata Metropolitan suburbs space and the influence of the urban activity pattern on the formation of the suburb's social structure. Thus, the study objectivesare to examine and analyze the increase in patterns of urban activity against changes in spatial use and the formation of social structures in the suburbs of Mamminasata Metropolitan.

\section{MATERIALS AND METHODS}

This research was carried out in three Mamminasata Metropolitan suburbs locations, namely Manggala,
Hertasning-Samata and Moncongloe-Pattalassang, all of which tend to develop into centers of economic growth, spatial integration and urban agglomeration. This investigation involved the use of a concurrent triangulation strategy approach where a combination of quantitative and qualitative techniques was applied simultaneously. Meanwhile, the reasons for this include describing the phenomena of spatial integration, changes in its use and systematic urban agglomeration, data collection, carried out through comparison with the possibility of combination and differentiation, merging of information which requires the need for interpretation and discussion. Furthermore, the three steps were conducted carefully and holistically based on the facts collected from the field, the individual or group characteristics and the relationship between the phenomena investigated (Creswell, 2016; Denzin and Lincoln, 2009).

The data collection methods include observation, used to measure and assess the spatial characteristics, space utilization, transportation systems and urban agglomeration in the Mamminasata Metropolitan suburbs. Survey which was conducted to evaluate the characteristics of the population, based on socio-economic conditions of the community and the inequality of land tenure, documentation was applied in the review of results obtained from several data sources including population data and density as well as the development of policies, related to development. Furthermore, the data analysis phase was initiated with the formulation of the basic hypotheses concept of the research, involving two stages which included, organizing research data where the information collected from field notes, surveys and observations were tabulated and categorized. Applying quantitative descriptive methods, based on the results of questionnaires and observations in order to create hypothesis which were then tested statistically on the established research variables.

Data analysis method: The methods of data analysis include, the qualitative analysis which was carried out through data collection, reduction, display and conclusion. These were further re-elaborated using domain evaluation, taxonomy, components and cultural themes. Quantitative analysis was used to prove the hypothesis of the research value. Therefore, both methods were used simultaneously to answer and prove the postulates including the effect of increasing patterns of urban activity on changes observed in the utilization of the Mamminasata Metropolitan suburbs space the effect of the pattern of these activities on the formation of its social structure.

Hypothesis testing was carried out by concurrent correlation using multiple regressions based on the characteristics and nature of the data which was ordinal. Furthermore, the evaluation of the effect (both direct and indirect) was carried out with the path analysis method using SPSS 23.00. 


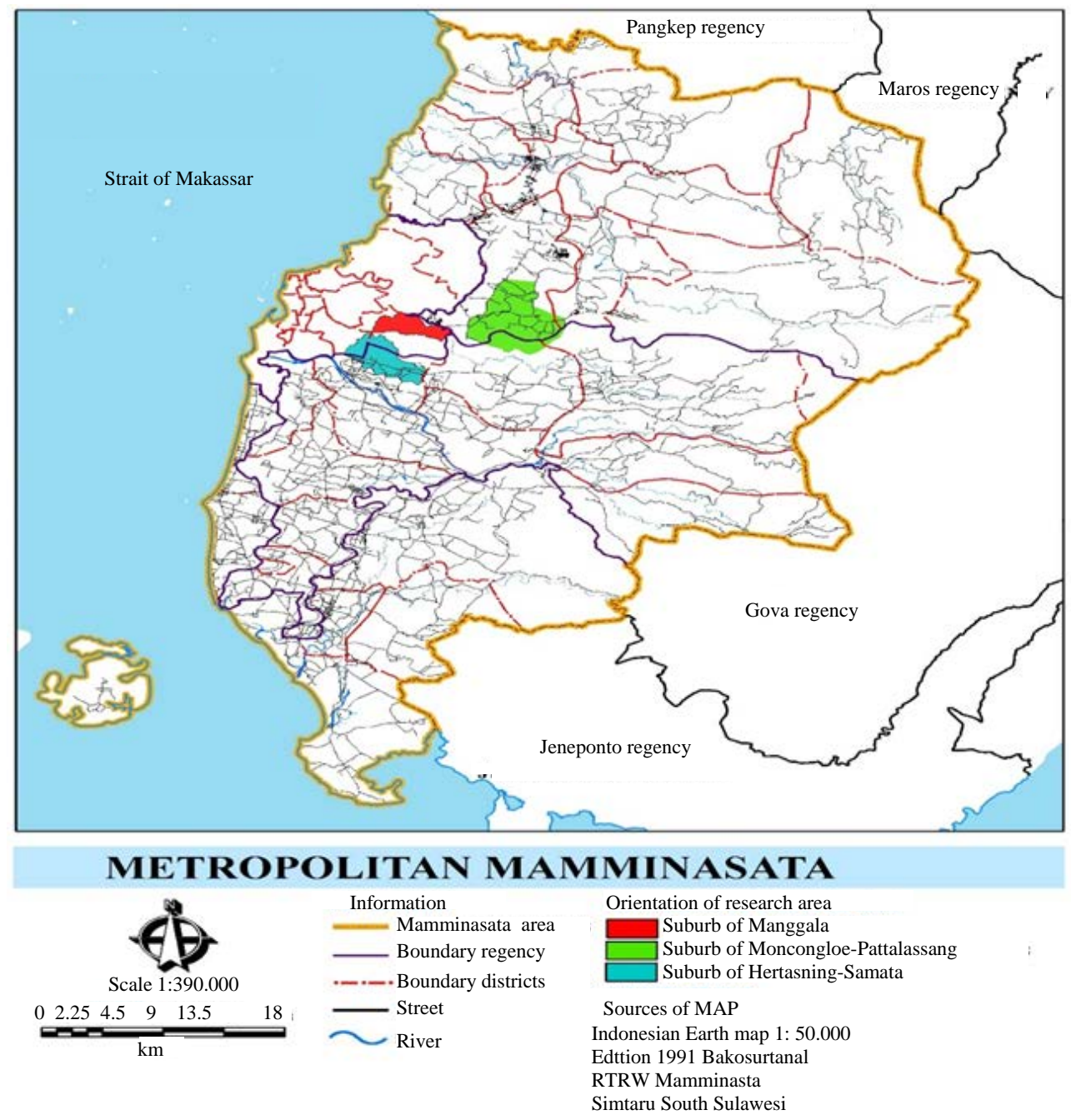

Fig. 1: Mamminasata Metropolitan suburbs as research objects; Satellite Imagery, 2018

\section{RESULTS AND DISCUSSION}

Development acceleration, marked by a shift in the functions of land use from productive agriculture to spatial and uneven distribution of development has an impact on the deterioration of environmental quality. This, alongside socio-economic development of local cities has reached or exceeded the carrying capacity of the environment and resources (Ye et al., 2019). However, changes in the space utility in the Mamminasata Metropolitan suburbs, lead to the positive association between an increase in population and fiscal activities, services, transportation infrastructure and large-scale settlements. Furthermore, this explosive population forces the city to become bigger and more complex than before, therefore, leading to an elevated demand for transportation and housing desires (Huang et al., 2019) as shown in Fig. 1.
Figure 2 shows a comparison between the various utility of Mamminasata Metropolitan suburbs space and three things that can be deduced regarding the process which include the increase in the conversion of farmland to settlements in Manggala of $29.70 \%$ (325.22 ha), between 2017-2018, the elevation in open land use of $26.51 \%$, causing the high (intensive) land conversion experience. Furthermore, the location with dense urban form had a higher probability to contain more facilities for activities and services than a low-density built environment (Lang et al., 2019).

In addition, to the space polarization in Makassar city center, another factor that determines the change in land use includes the increase in population as a result of urbanization and suburbanization which is a measure adopted to meet the residential needs, socio economic activities and infrastructure, further influence the dynamics of the community. This increases the 

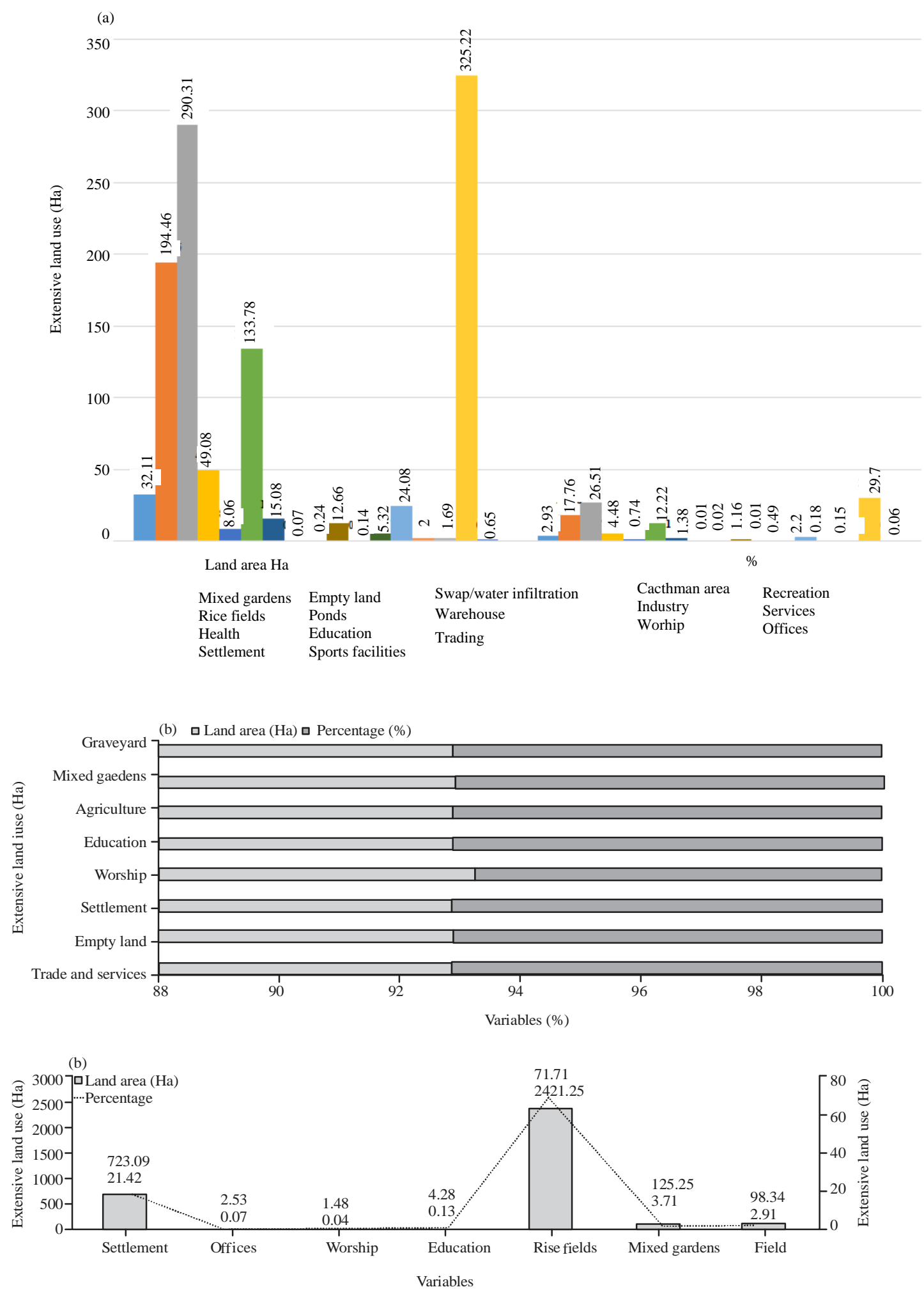

Fig. 2(a-c): The use of the Mamminasata Metropolitan urban suburbs space in 2010-2018 field observation results and Satellite Imagery, 2018, (a) Manggala urban suburbs, (b) Hertasning-Samata urban Suburbs and (c) Moncongloe-Pattalassang suburbs 
concentration of people and critical services in cities which also upscale their exposure to acute shocks and long-term stresses such as floods, earthquakes, climate change or social dynamics (Hernantes et al., 2019).

The Hertasning-Samata suburbs showed an increase in land use to settlements of $47.93 \%$ (621.45 ha) which was intended to meet the needs of residential facilities for the urban population of Mamminasata Metropolitan. Hence, it can be concluded that urbanization leads to changes in spatial use and subsequently, environmental dilapidation in the Hertasning-Samata suburbs. However, ecological degradation gradually exhibits a limiting effect on socioeconomic subsystem, further restricting the improvement of the coordinated development (Yang and Hu, 2019).

The horizontal change in spatial use, characterized by the existence of urban activity functions which develops linearly, along the road corridor has a positive correlation with the dynamics of spatial transformation and economic growth of suburbs. Furthermore, the accessibility to the main roads, cities and services positively affected while the proximity to industrial lands most negatively influenced growth patterns (Dadashpoor et al., 2019). This is characterized by centralized urban activities in certain locations, leading to agglomerations and sprawl or shrinkage which indicates the expansion of the built area, therefore, causing environmental degradation in the city area (Patra et al., 2018). However, facts gathered from the field show that the Hertasning-Samata road corridor contributes to the increase in the rate of urbanization and local economic productivity which is positively associated with the conurbation that leads to the integration of the Metropolitan Mamminasata municipal system. Local economic factors and the spatial influence of the infrastructure network both contribute to the changes in urbanization to a varying extent (Zeng et al., 2019).

In 2018, Moncongloe-Pattallassang suburbs showed an increase in residential land by 723.09 ha. Thus, its spatial characteristics changed from rural to urban. Hence, physical configuration, population as well as socio-economic activities, significantly developed (Olajide et al., 2018).

Facts collected from the fields showed that about $80 \%$ of the $3,376.22$ ha of land in this area was initially productive plantations for agriculture which declined after changes in ownership and the initiation of development in residential areas. Therefore, the relationship between urban depreciation and economic growth provides important information for the government in the formulation of urban development policies (Zhang et al., 2019).

Increasing the farmland conversion rate directly encourages the development of linear and concentric municipal activities, therefore, causing a decrease in the environmental quality and morphology of urban suburbs
(Surya et al., 2018b). Meanwhile, the implications are observed through the changes in the structure and pattern of space as well as the presence of a considerable potential role in regional and rural development in the Mamminasata Metropolitan urban area (Rasoul, 2017). Furthermore, the alteration in spatial structure and its associated effects on the Moncongloe-Pattalassang suburbs led to a modification in the urban transportation system and increased connectivity between urban areas of Makassar city, the system of Maros regency and that of Gowa regency. However, this road network is one indicator which measures the sustainability of municipal deployment for existing and new urban areas (Ahmadzai et al., 2019). Furthermore, another follow-up uncoordinated and unplanned impacts that arise from these changes include environmental ecosystem changes, agricultural land cover and water catchment areas along the periphery of the metropolitan, leading to shrinkage of environmental resources (Nengroo et al., 2017).

The level of accessibility to these areas is basically measured by the availability of road infrastructure, transportation modes as well as distance and travel time. Hence, it can be concluded that the suburbs under study possess a fairly high level of ease of access. Furthermore, the facts gathered from the field shows that road corridors support the interconnection of these municipal areas including itsopenness through, Antang Raya road, Borong Raya road, Batua Raya road and Tamangapa Raya road and the Hertasning-Samatastreet corridor.

Figure 3 shows the condition of road infrastructure in the Mamminasata Metropolitan suburbs which are generally of two types, asphalt and concrete, measuring 8-12 m. However, facts gathered from the field shows that the transportation infrastructure facilitates accessibility from the city center to suburbs and vice versa. Hence, the functional socio-economic transport system is capable of accommodating the mobility, safety, comfort and convenience of all inhabitants (Soyinka et al., 2016). Therefore, Makassar city, Maros regency and Gowa regency have a fairly high intensity of mobilization.

Connectivity among these areas and inadequate policy implementation cause differences in resource distribution and disparity in their services based on population grouping (Ngoran and Xue, 2015). However, the facts obtained in the field show that the confluence of mobilization from Makassar city to Maros regency and Gowa regency places the Mamminasata Metropolitan suburbs in crossing line. Therefore, spatial strategic planning is an important factor in coordinating activities of individuals, groups, organizations as well as the private sector (Lalehpour, 2016).

The complexity of the dynamic allocation of space for socio-economic activities and urban agglomeration has led to the formation of functional areas of unity with the 
(a)

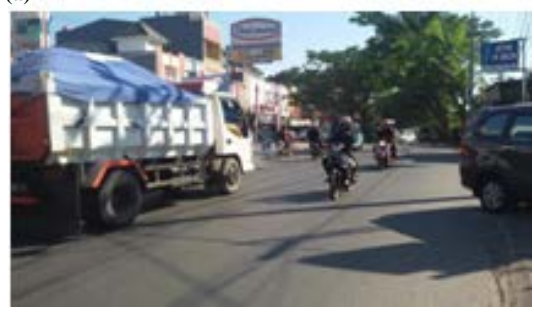

(b)

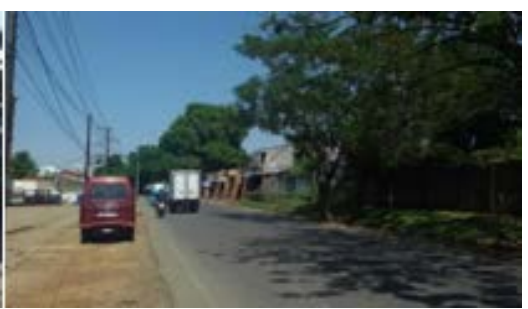

(c)

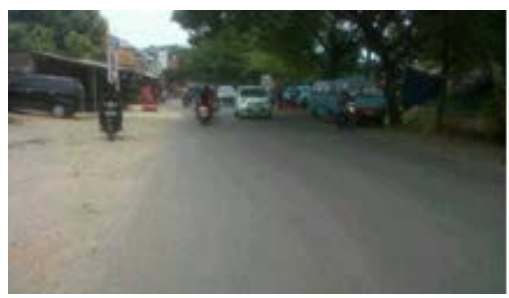

Fig. 3(a-c): Accessibility towards the Mamminasata Metropolitan urban suburbs

city concerned, comprising the central and also its suburbs (Suzuki and Nijkamp, 2018). There are two types of spatial expressions related to changes its use in the Mamminasata Metropolitan suburbs including linear pattern or manner and concentric physical development. Meanwhile, each of them is capable of standing alone or appearing simultaneously which means that centrifugal advancement shows the complexity of spatial expression. Therefore, the complexities of activity patterns tend to be sporadic are positively associated with the progress within slums mostly inhabited by local communities. Hence, the typology of these areas includes houses on stilts with inadequate infrastructure conditions (Surya and Saleh, 2018).

The process physical development of centrifuges has an undeviating positive contribution to the expansion of suburbs and also directly changing the spatial structure and pattern of the municipal space in Mamminasata Metropolitan. Furthermore, planning initiatives are also employed within social systems that are governed by the institution which also intervenes with and may further reconfigure these institutions, therefore, resulting in social changes (Rahman, 2016). This polarization also has a direct impact on the additional areas built towards economic urbanization because large metropolitan areas where the positive factors associated with it as well as the negative factors of diseconomization, coexist (Nakamura, 2013). Hence, alongside the main road corridor is the area, built towards Gowa regency and Maros regency and the linear pathway controls the growth of settlements and shopping centers by creating more linear over than concentric spatial patterns (Surya, 2015a).

Figure 4 shows the development of the Mamminasata Metropolitan suburbs space structure in both linear and concentric manner as those that occur along the main road corridors, generally include residential areas, shopping centers, services and economic activities. Field reports indicate the ease to carry out morphological control outside the built area which currently has an empty land with relatively flat topography (Surya, 2015c).

The physical spatial development of centrifuges and concentricity's was related to social, economic and cultural changes which occur in the life of infiltrative and expansive migrants as well as local communities. Meanwhile, field reports show that the Mamminasata Metropolitan suburbs were in transition from rural to municipal as a result of urbanization and suburbanization. This rapid process, alongside ad hoc and unplanned spatial distribution and allocation of spatial activities has an impact on decreasing the quality of the environment quality (Qiu et al., 2015). Furthermore, the spatial structure leads to alterations and formation of social territorial structures due to differentiation and increasing scale of modern industrial society. However, there are three cases that underlie the process which include distribution, range and intensity of the relationship between migrants and local communities, differentiation of space functions and complexity of spatial organizations. Conversely, observed facts show these changes to possess a positive influence on the social relationship between migrants and local communities, towards economic alterations (Surya et al., 2018 c). Therefore, the scale of social transformation increases and is marked by the vicissitudes in the lifestyle of the urban community (Surya, 2016 b).

Characteristics of urban economic suburbs: The acceleration in economically oriented growth of the 


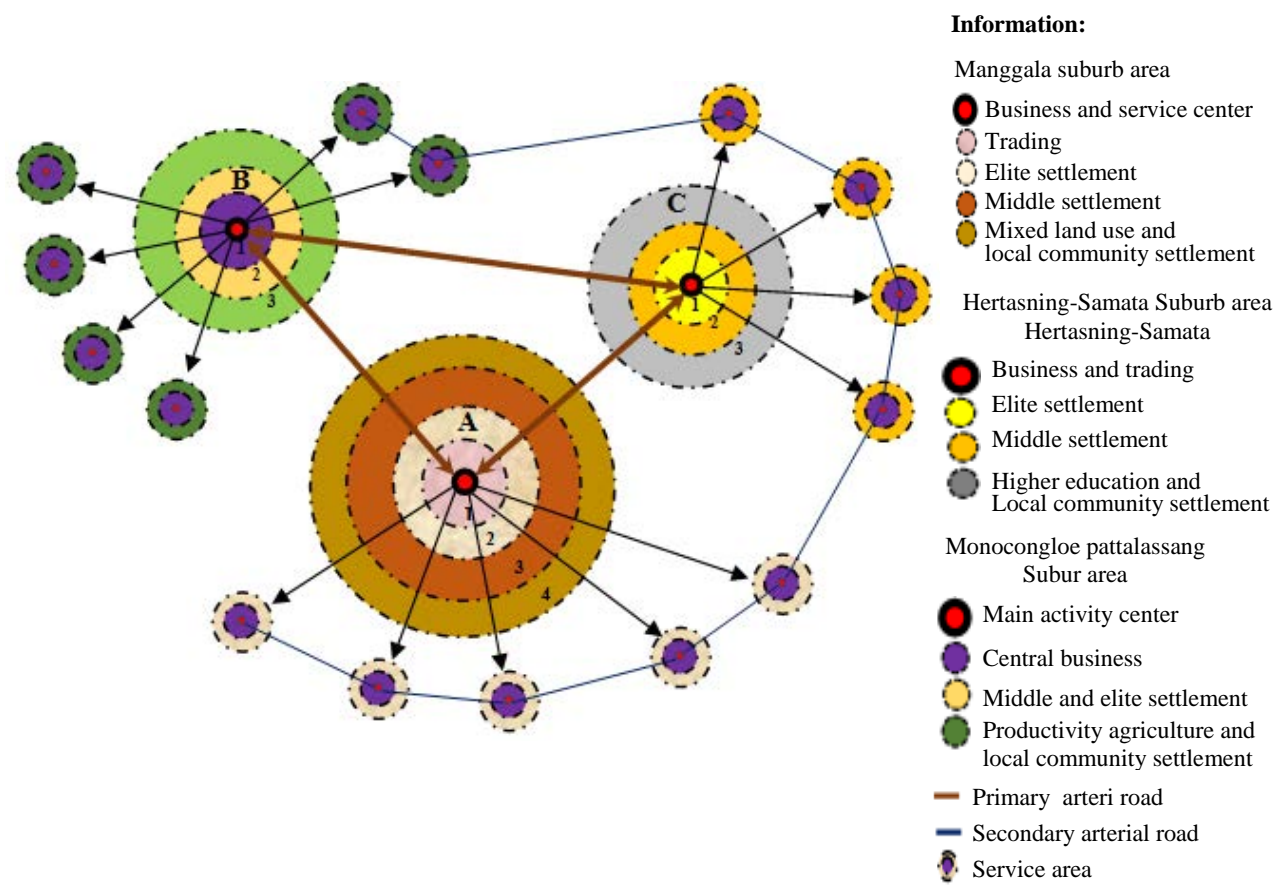

Fig. 4: Comparison of the Mamminasata Metropolitan suburbs space structure analysis result

Mamminasata Metropolitan suburbs also affected changes in land ownership status. These increased the price at a function of its position and location and the comparison is shown in Fig. 4.

Figure 5 shows a comparison of the price of land in the urban suburbs of Mamminasata Metropolitan and three things that can be explained in relation to the changes in the suburbs observed include its value in the Manggala is IDR 1,000,000-5,000,000 $\mathrm{m}^{-2}$, influenced by the location, distance and position, the price of plots in Hertasning-Samata was elevated from Rp. $50,000 \mathrm{~m}^{-2}$ to Rp. 1,000,000 within the built settlement and Rp. 4, $000,000 \mathrm{~m}^{-2}$ for those along the main road corridor. Furthermore, the amount for land in Moncongloe Pattalassang is Rp. 1, 000,000-3,000,000 $\mathrm{m}^{-2}$. Hence, it can be concluded that its value and price in the Mamminasata Metropolitan suburbs was largely determined by the development of the economic activity, meaning that the closeness of land to these functions, positively correlates with the elevation of value and vice versa. However, differences between the city centers and peripheral locations indicate the important role sites play in combination with income and governance factors (Acolin et al., 2019).

The rapid acceleration of development has a positive correlation with changes in social formation and interaction within the urban suburbs of Mamminasata Metropolitan in response to the stimulus of environmental change. Furthermore, the adaptation process, carried out by the local community, towards infiltrative migrants involved the provision of accommodation in a residential environment and their willingness to build mutually beneficial cooperation. Hence, it is important for the population to understand population-environmental relations (Ma and Hofmann, 2019). Information from the field showed that mutual acceptance among communities possesses the capacity to strengthen social relations, leading to welfare improvement. Therefore, interactive values are generated from the meeting point of motivation which develops towards social relations ( Mohamed et al., 2019).

Different conditions are shown in the process of migrant social adaptation which is dominantly geared towards land tenure, space reproduction and local community empowerment as workers. Therefore, it can be concluded that changes in spatial use determine social formation and differentiation of economic business activities, towards inequality in land tenure by disregarding various policy contributions towards inequality in developing countries (Forster et al., 2019). Furthermore, the discriminatory relationship between low and middle income earners causes financial inequality (Sulemana and Kpienbaareh, 2018). Conversely, the simultaneous coexistence of production modes, characterized by job differentiation, leads to differences in the processes of social interaction and adaptation between local communities and migrants in the urban suburbs of Mamminasata Metropolitan.

The differences observed in patterns of social relationships, based on the type of business, work orientation and fragmentation in the lives of local 

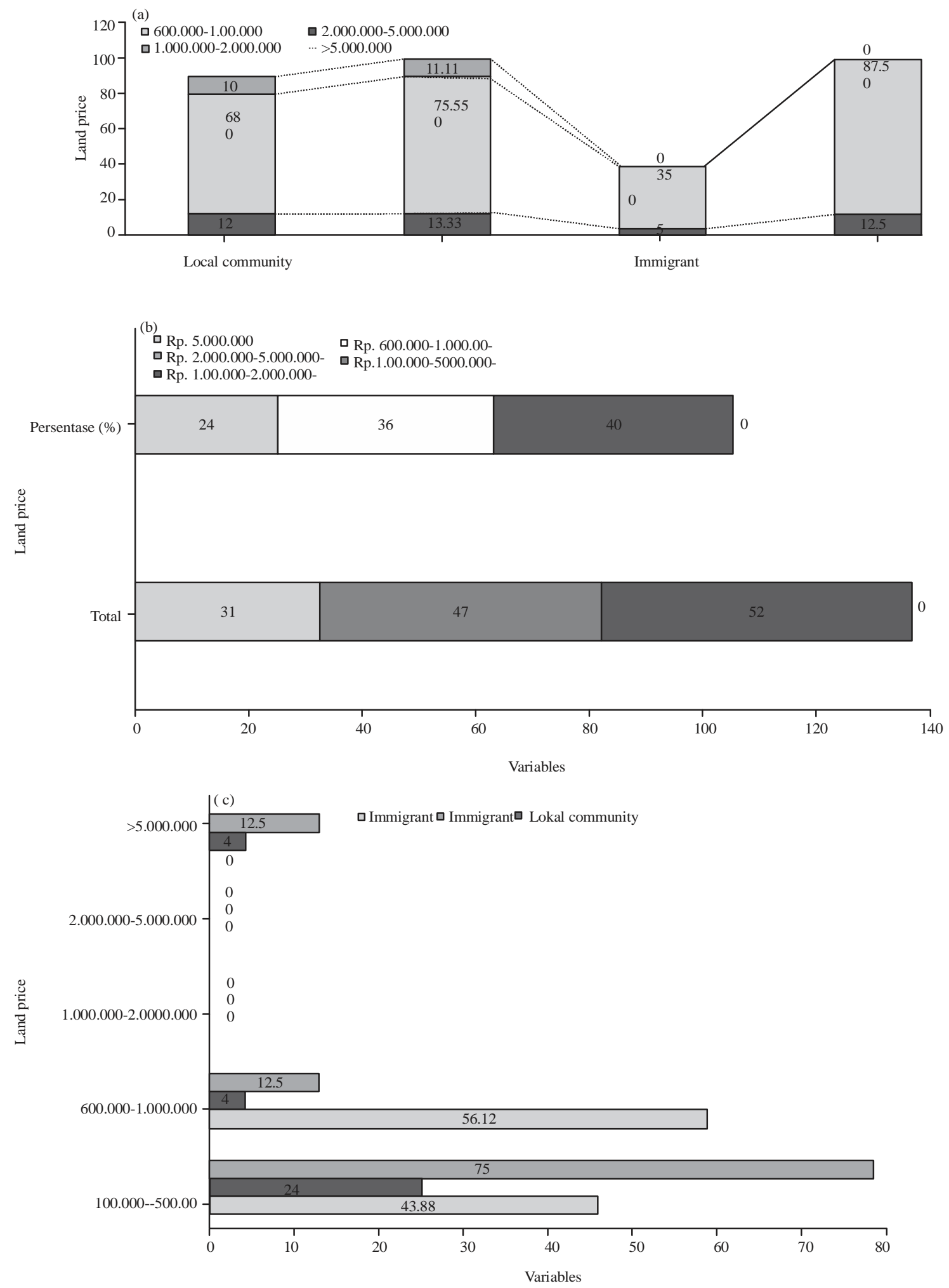

Fig. 5(a-c): Effect of increased patterns of urban activities on changes in the utilization of the Mamminasata Metropolitan suburbs space analysis result, (a) Land price in Manggala suburn, (b) Land price in hertasning Samata and (c) Land price in Moncongloc-Pattalassang 
J. Eng. Applied Sci., 15 (6): 1273-1288, 2020

Table 1: Matrix of differences in social relations based on local community work orientations

\begin{tabular}{|c|c|c|c|c|}
\hline \multicolumn{5}{|c|}{ Characteristics of social relations } \\
\hline Business activities & Pre-changes in spatial use & Social relations & Post-changes in spatial use & Social relations \\
\hline $\begin{array}{l}\text { Informal sector } \\
\text { (street vendors) }\end{array}$ & $\begin{array}{l}\text { Relations with the } \\
\text { core family } \\
\text { Relationship with } \\
\text { close relatives } \\
\text { Relationships with local } \\
\text { community groups }\end{array}$ & $\begin{array}{l}\text { High intensity and } \\
\text { reciprocity and } \\
\text { mutual benefit }\end{array}$ & $\begin{array}{l}\text { Relationship with close } \\
\text { relatives } \\
\text { Relationship with business } \\
\text { relations } \\
\text { Relationships with community } \\
\text { groups } \\
\text { Relationship with consumers } \\
\text { (buyer) }\end{array}$ & $\begin{array}{l}\text { Low frequency } \\
\text { Reciprocity and mutual benefits } \\
\text { through agreements that are built } \\
\text { Low frequency only lasts in certain } \\
\text { situations } \\
\text { Mutually beneficial (mutualism } \\
\text { symbiosis) }\end{array}$ \\
\hline $\begin{array}{l}\text { Parking attendants } \\
\text { at economic activity } \\
\text { centers }\end{array}$ & $\begin{array}{l}\text { Relations with the core } \\
\text { family } \\
\text { Relationship with close } \\
\text { relatives } \\
\text { Relationships with local } \\
\text { community groups }\end{array}$ & $\begin{array}{l}\text { High intensity is } \\
\text { reciprocal and helps } \\
\text { each other based on } \\
\text { togetherness values }\end{array}$ & $\begin{array}{l}\text { Relationship with close relatives } \\
\text { Relationship with work relations } \\
\text { Relationships with community } \\
\text { groups } \\
\text { Relationship with visitors }\end{array}$ & $\begin{array}{l}\text { Low frequency } \\
\text { Mutually beneficial and reciprocal } \\
\text { cooperation relationships } \\
\text { One-way nature to maintain } \\
\text { harmonization of local community } \\
\text { groups } \\
\text { Mutually beneficial }\end{array}$ \\
\hline $\begin{array}{l}\text { Building } \\
\text { construction }\end{array}$ & $\begin{array}{l}\text { Relations with the } \\
\text { core family } \\
\text { Relationship with } \\
\text { close relatives } \\
\text { Relationships with local } \\
\text { community groups }\end{array}$ & $\begin{array}{l}\text { High intensity is } \\
\text { reciprocal and helps } \\
\text { each other based on } \\
\text { togetherness values }\end{array}$ & $\begin{array}{l}\text { Relationship with work relations } \\
\text { Relationships with community } \\
\text { groups } \\
\text { Relationship with close relatives } \\
\text { Relations with building supervisors }\end{array}$ & $\begin{array}{l}\text { High frequency and mutual reciprocity } \\
\text { High frequency and is related to the } \\
\text { profession that is lived and fosters } \\
\text { mutual solidarity } \\
\text { High frequency by involving } \\
\text { families as workers and reciprocal } \\
\text { One-way (control over work) }\end{array}$ \\
\hline Formal workers & $\begin{array}{l}\text { Relations with the } \\
\text { core family } \\
\text { Relationship with } \\
\text { close relatives } \\
\text { Relationships with } \\
\text { local community groups }\end{array}$ & $\begin{array}{l}\text { High intensity is } \\
\text { reciprocal and helps } \\
\text { each other based on } \\
\text { togetherness values }\end{array}$ & $\begin{array}{l}\text { Relationship with close relatives } \\
\text { Relationships with community } \\
\text { groups } \\
\text { Relationship with work relations } \\
\text { Relations with management } \\
\text { Relationship with visitors }\end{array}$ & $\begin{array}{l}\text { Low frequency } \\
\text { Low frequency and only takes } \\
\text { place in certain situations } \\
\text { High frequency, mutually } \\
\text { supportive and reciprocal } \\
\text { Class contradictory relationship } \\
\text { High frequency and reciprocal }\end{array}$ \\
\hline
\end{tabular}

Result analysis

Tabele 2: Changes in social stratification in local communities

\begin{tabular}{ll}
\hline Old social stratification & New social stratification \\
$\begin{array}{l}\text { The social coating is characterized by land ownership } \\
\text { The developing social strata are characterized by an } \\
\text { economic class structure based on two strata classification } \\
\text { namely farm laborers and land owners }\end{array}$ & $\begin{array}{l}\text { The social coating is characterized by the complexity of the } \\
\text { activities of local communities } \\
\text { The developing social strata are characterized by an economic } \\
\text { cocial relations are a small takeover }\end{array}$ \\
$\begin{array}{l}\text { The power structure is lineage } \\
\text { economic enterprises, building construction workers, } \\
\text { Variation in wealth is indicated by ownership of means } \\
\text { of production and ownership of land }\end{array}$ & $\begin{array}{l}\text { Social relations are groups of workers } \\
\text { The power structure is based on the achievements } \\
\text { of the local community }\end{array}$ \\
& $\begin{array}{l}\text { Variation in wealth is not based on land ownership but is based } \\
\text { on the ability of local community businesses to respond to a } \\
\text { stimulus for environmental change }\end{array}$ \\
\hline
\end{tabular}

communities is shown in Table 1 . Hence, it can be concluded that changes in the use of space in the Mamminasata Metropolitan suburbs indicates differences in the type of social and economic relations built in the local community whose pattern was originally characterized by gemeinschaf or tight social ties which changed towards gesselschaft or voluntary and contractual public ties (Surya, 2015b). Rapid revolutionary changes influence the formation of new communal territorial structures in the Mamminasata Metropolitan suburbs based on stratification and economic background.

Interpretations that can be proposed based on the data on Table 2 include the social coating that develops in the structure of local communities leads to complexities that are based on land ownership while the changes observed in stratification was influenced by the work and land ownership system as well as the related patterns of employment. This means that the nature of change is dominantly influenced by the presence of capitalism which acts as an agent of change, trusted by the government. However, the complexity of social coating leads to a gap in the tenure of spatial reproduction and income inequality and evidence shows a positive association with urbanization (Sulemana et al., 2019). The developing social strata are influenced by changes in spatial use and differences in the orientation of local community work. Public relations are strongly influenced by forms of cooperation, built into the structure of local communities. The structure of power in terms of social status is not based on lineage but abilities and 

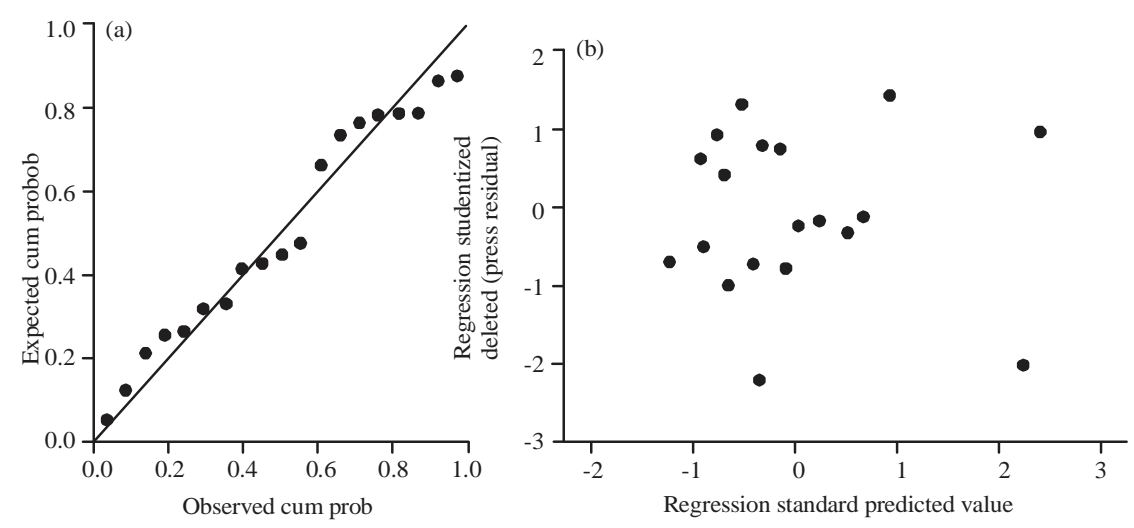

Fig. 6(a, b): Effect of patterns of urban activities on the changes in the utilization of the Mamminasata Metropolitan suburbs space

Table 3: Effect of increased activity on changes in spatial use of the Mamminasata Metropolitan suburbs model summary

\begin{tabular}{lcccr}
\hline Modeles & $\mathrm{R}$ & $\mathrm{R}^{2}$ & Adjusted $\mathrm{R}^{2}$ & SE of the estimate \\
\hline 1 & $0.918^{\mathrm{a}}$ & 0.842 & 0.684 & 5.213 \\
2 & $0.914^{\mathrm{b}}$ & 0.836 & 0.705 & 5.037 \\
3 & $0.906^{\mathrm{c}}$ & 0.821 & 0.707 & 5.022 \\
\hline
\end{tabular}

Predictors: (Constant), investment/capital flows, economic activities, social activities, facilities and infrastructure, services, availability of land, housing and settlements, informal economy, transportation system; ${ }^{\text {a }}$ Predictors (Constant), investment/capital flows, economic activities, social activities, facilities and infrastructure, services, land availability, informal economy, transportation system; ${ }^{\mathrm{b}}$ Predictors (constant), investment/capital flows, economic activities, social activities, facilities and infrastructure, services, land availability, transportation systems

achievements instead. Variations in wealth are based more on the ability to respond to a stimulus for environmental change. Furthermore, the five parameters cause the social coating of the community in the urban suburbs of Mamminasata Metropolitan.

Spatial integration and economic growth: The development of spatial integration and economic growth contributes positively to the intensity of business centers, large-scale settlements, services, offices, education and other socio-economic activities. This framework and arrangement of retail planning require the support of political decision making (Brunetta et al., 2018). Facts gathered from the field showed that this expansion was followed by the dynamics of urban informal fiscal activities carried out by local communities, alongside formal economic events, causing urban sprawl based on the comparison between the rate of population growth and that of built-up areas (Buchori et al., 2017). The results of statistical tests are shown in Table 3 and Fig. 4.

The backward method the best regression equations obtained: $\mathrm{Y}=20,150-0.439 \mathrm{X} 1+1.159 \mathrm{X} 2+0.221 \mathrm{X} 3-$ $0.210 X 4-0.560 X 5+0.642 X 5-0.749 X 6 ; \mathrm{R}_{\text {square }}=0.821$. This was obtained by removing the variables of housing, settlements and the informal economy in order to consider the significant effect of independent variables on the spatial use.
Table 3 and Fig. 6 show the effect of increasing patterns of urban activity on changes in spatial use in the suburbs of Mamminasata Metropolitan, some of which are explained based on the results of the analysis which include: $\mathrm{R}^{2}=0.698=69.80 \%$ characterized by 9 independent variables including investment/capital flows, economic and social activities, facilities and infrastructure, services, availability of land, housing and settlements, informal economy and transportation system. However, the remaining $(100-69.80 \%=30.20 \%)$ is explained by other reasons, outside the scope of this model. The results of the ANOVA F test table obtained a count value of 5,872 with a probability of 0.005 which indicates the probability of using regression models to predict changes in spatial use. This can also be applied in the explanation of the nine independent variables, jointly influence the utilization of space in the Mamminasata Metropolitan suburbs. Furthermore, out of the nine included in the regression model, the following were not significant: economic activity variables $=0.080$, social activities $=0.055$, housing and settlement $=0.528$ and formal economy $=0.336$ as seen from the probability of significance while the availability of land, transportation systems, services, facilities and infrastructure and investment/capital flows were significant at 0.05 . Hence, they are concluded to have an influence on spatial use.

From the analysis of the results, the following can be explained if the independent variable is considered 

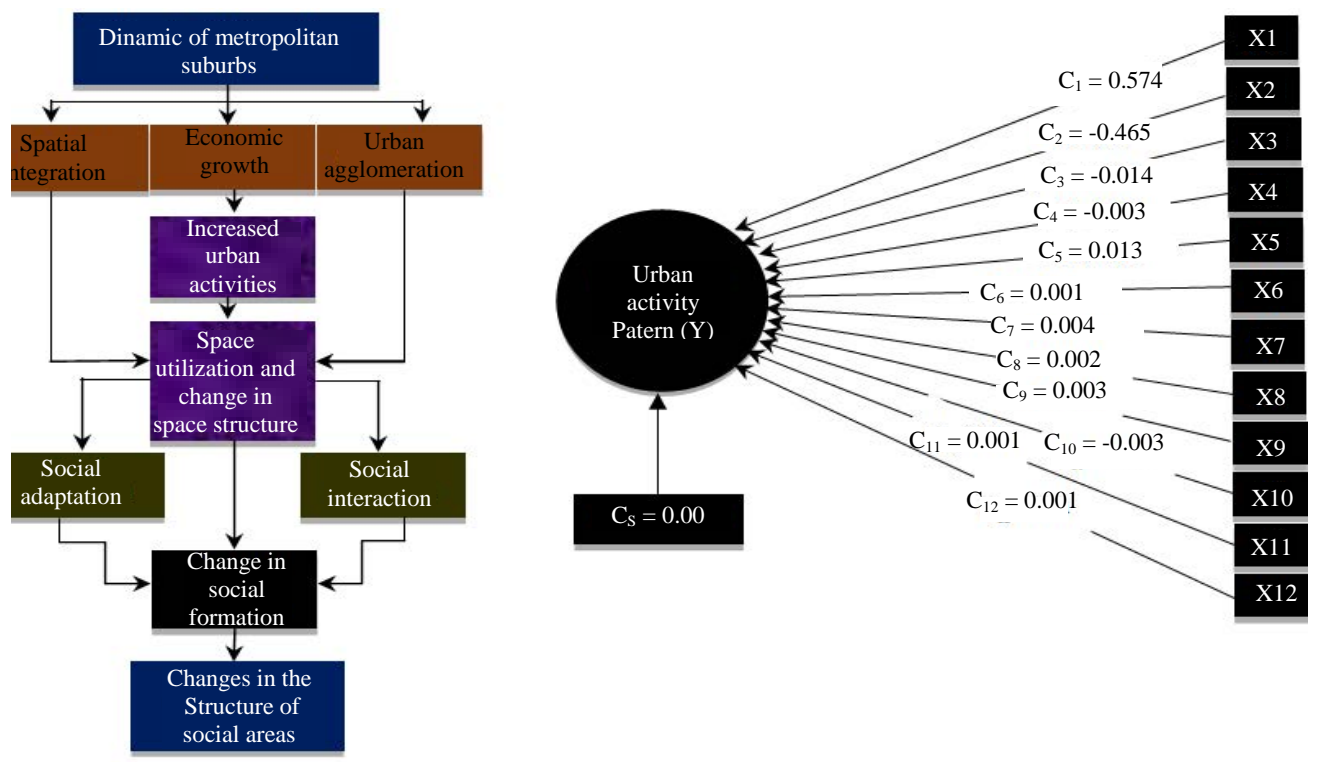

Fig. 7: Effect of patterns of urban activities on the formation of the structure of social areas analysis result

constant, the average spatial use is 27,116 . The regression coefficient of land availability, reading -0.404 , indicates that every 1000 added, reduces spatial use by 404 units. The transport system test value of 1.139, states that subsequent addition of 1000 increases spatial use by 1.139 units. The increase in service by 1000 reduces the use by 526 units as seen in the coefficient value of - 0.526 . (d) coefficient of facilities and infrastructure of 0.643 states that every addition of facilities and infrastructure equal to 1000 will add spatial use of 643 units. The investment/capital flow regression coefficient of $-0,694$ states that every additional investment/capital flow of 1000 will reduce spatial use by 694 units. Thus it can be concluded that the pattern of urban activity that continues to increase in line with economic growth will trigger spatial integration and change in spatial use in the urban suburbs of the Mamminasata Metropolitan and have a direct influence on the surrounding urban and rural areas.

The best regression model was obtained by removing the variables of housing and settlements as well as the formal economy in order for only the independent variables, considered to significant influence spatial use variables. This assessment was carried out in 3 stages which include analysis using the enter method, meaning that all variables are included in the model in order to produce a regression model: $\mathrm{Y}=27,549-$ $0.411 \mathrm{X} 1+1.151 \mathrm{X} 2+0.186 \mathrm{X} 3-0.210 \mathrm{X} 4-0.060 \mathrm{X} 5$ $+0.546 X 6-0.096 X 7+0.644 X 8-0.701 X 9 ; \mathrm{R}_{\text {square }}=0.842$. Analysis with the backward method, through the issued housing and settlement variables (Probability of F-to remove $>=0.100$ ) from the model in order to form the regression: $\mathrm{Y}=23,473-0.425 \mathrm{X} 1+1.155 \mathrm{X} 2+0.193 \mathrm{X} 3-$ $0.228 X 4-0.558 X 6+0.105 \times 7+0.633 X 8-655 X 9 ; \mathrm{R}_{\text {square }}=$ 0.836 and . Analysis with the backward method, through the allotment of housing and settlement as well as informal economy variables (Probability of F-to-remove $>=0.100$ ) from the model, so that, a new regression model is formed: $\mathrm{Y}=20,150-0.439 \mathrm{X} 1+1.159 \mathrm{X} 2+$ 0.221X3-0.210X4-0.560X6+0.642X8-0.749X9; $\mathrm{R}_{\text {square }}=$ 0.821 .

The agglomeration of urban suburbs: Economic growth which runs parallel to spatial integration in the Mamminasata Metropolitan suburbs, causes changes in spatial attributes, morphology, typology and rural characteristics towards urbanization. This growth produces extensive ecological and environmental problems both in municipal and suburban areas (Tan et al., 2014). Therefore, the results of the analysis carried out on the effect of these activity patterns on the formation of social territorial structures in the studied region are shown in Table and Fig. 6.

\section{Structural equations:}

$\mathrm{Y}=0.574 \mathrm{X} 1+(-0.465) \mathrm{X} 2+(-0.014) \mathrm{X} 3+0.003 \mathrm{X} 4+$ $0.013 X 5+0.001 \times 6+0.004 \times 7+0.002 \times 8+0.003 \mathrm{X} 9+(-$ $0.003) \mathrm{X} 10+0.001 \mathrm{X} 11+(-0.001) \mathrm{X} 12+0 \varepsilon ; \mathrm{R}_{\text {square }}=$ 1.000 .

The results of the analysis in Table 4-10 and Fig. 7, explains three points which include (i) the magnitude of the coefficient terminated R square or R2Y $\times 1 \times 2 \times 3, \ldots$, $\times 13=1.000$ as well as the influence of other variables $=$ $\sqrt{ } 1-1=0 \%$ which means that there is no influence or contribution from other affiliates (0\%). Thus, it can be concluded that the studied parameters directly influence the formation of social territorial structures which develop in the Mamminasata metropolitan suburbs, the results 
J. Eng. Applied Sci., 15 (6): 1273-1288, 2020

Table 4: Effect of increased activity on changes in spatial use of the Mamminasata Metropolitan suburbs ANOVA ${ }^{\text {a }}$

\begin{tabular}{llrrrr}
\hline Models & Sum of squares & df & Mean square & F-value & Sig. \\
\hline Regression & 1305.111 & 9 & 145.012 & 5.336 & $0.010^{\mathrm{b}}$ \\
Residual & 244.573 & 9 & 27.175 & & \\
Total & 1549.750 & 18 & & 6.384 & \\
Regression & 1295.923 & 8 & 161.990 & & \\
Residual & 253.761 & 10 & 25.376 & & \\
Total & 1549.684 & 18 & & & \\
Regression & 1272.276 & 7 & $2004^{\mathrm{c}}$ \\
Residual & 277.408 & 11 & 25.219 & & $0.002^{\mathrm{d}}$ \\
Total & 1549.684 & 18 & & & \\
\hline
\end{tabular}

Dependent variable: spatial use; ${ }^{2}$ Predictors: (Constant), investment/capital flows, economic activities, social activities, facilities and infrastructure, services, availability of land, housing and settlements, informal economy, transportation system; ${ }^{\mathrm{c}}$ Predictors: (Constant), investment/capital flows, economic activities, social activities, facilities and infrastructure, services, land availability, informal economy, transportation system; ${ }^{\mathrm{d}}$ Predictors: (Constant), investment/capital flows, economic activities, social activities, facilities and infrastructure, services, land availability, transportation systems

$\underline{\text { Table 5: Effect of increased activity on changes in spatial use of the Mamminasata Metropolitan suburbs coefficients }{ }^{\mathrm{a}}}$

\begin{tabular}{|c|c|c|c|c|c|}
\hline \multirow[b]{2}{*}{ Models } & \multicolumn{2}{|c|}{ Unstandardized coefficients } & \multicolumn{3}{|c|}{ Standardized coefficients } \\
\hline & $\mathrm{B}$ & SE & Beta & t-values & Sig. \\
\hline 1 (Constant) & 27.549 & 20.286 & & 1.358 & 0.208 \\
\hline Improving land & -0.411 & 0.103 & -0.868 & -3.978 & 0.003 \\
\hline Transportation system & 1.151 & 0.196 & 1.592 & 5.872 & 0.000 \\
\hline Economic activity & 0.186 & 0.099 & 0.292 & 1.879 & 0.093 \\
\hline Social activities & -0.210 & 0.101 & -0.318 & -2.081 & 0.067 \\
\hline Housing and settlement & -0.060 & 0.103 & -0.101 & -.581 & 0.575 \\
\hline Services & -0.546 & 0.170 & -0.663 & -3.217 & 0.011 \\
\hline Informal economy & -0.096 & 0.113 & -0.150 & -.844 & 0.421 \\
\hline Infrastructure & 0.644 & 0.118 & 1.044 & 5.472 & 0.000 \\
\hline Invesment/capital flows & -0.701 & 0.225 & -0.718 & -3.115 & 0.012 \\
\hline 2 (Constant) & 23.473 & 18.395 & & 1.276 & 0.231 \\
\hline Improving land & -0.425 & 0.097 & -0.896 & -4.356 & 0.001 \\
\hline Transportation system & 1.155 & 0.189 & 1.598 & 6.104 & 0.000 \\
\hline Economic activity & 0.193 & 0.095 & 0.302 & 2.023 & 0.071 \\
\hline Social activities & -0.228 & 0.093 & -0.345 & -2.447 & 0.034 \\
\hline Housing and settlement & -0.558 & 0.163 & -0.678 & -3.430 & 0.006 \\
\hline Services & -0.105 & 0.109 & -0.164 & -.965 & 0.357 \\
\hline Informal economy & 0.633 & 0.112 & 1.026 & 5.637 & 0.000 \\
\hline Infrastructure & -0.655 & 0.204 & -0.671 & -3.218 & 0.009 \\
\hline Invesment/capital flows & 20.150 & 18.014 & & 1.119 & 0.287 \\
\hline 3 (Constant) & -0.439 & 0.096 & -0.927 & -4.576 & 0.001 \\
\hline Improving land & 1.159 & 0.189 & 1.602 & 6.142 & 0.000 \\
\hline Transportation system & 0.221 & 0.090 & 0.346 & 2.441 & 0.033 \\
\hline Economic activity & -0.210 & 0.091 & -0.317 & -2.307 & 0.042 \\
\hline Social activities & -0.560 & 0.162 & -0.681 & -3.457 & 0.005 \\
\hline Housing and settlement & 0.642 & 0.112 & 1.042 & 5.759 & 0.000 \\
\hline Services & -0.749 & 0.178 & -0.768 & -4.213 & 0.001 \\
\hline Informal economy & 27.549 & 20.286 & & 1.358 & 0.208 \\
\hline Infrastructure & -0.411 & 0.103 & -0.868 & -3.978 & 0.003 \\
\hline Invesment/capital flows & 1.151 & 0.196 & 1.592 & 5.872 & 0.000 \\
\hline
\end{tabular}

Dependent variable: use of space

Table 6: Effect of increased activity on changes in spatial use of the Mamminasata Metropolitan suburbs excluded variables ${ }^{\mathrm{a}}$

\begin{tabular}{|c|c|c|c|c|c|}
\hline & & & & & Collinearity statistics \\
\hline Models & Beta in & t-values & Sig. & Partial correlation & Tolerance \\
\hline Settlement and housing & $-0.101^{\mathrm{b}}$ & -0.581 & 0.575 & -0.190 & 0.577 \\
\hline Settlement and housing & $-0.122^{\mathrm{c}}$ & -0.715 & 0.491 & -0.220 & 0.588 \\
\hline Economic in formal & $-0.164^{c}$ & -0.965 & 0.357 & -0.292 & 0.566 \\
\hline
\end{tabular}

obtained from the ANOVA table showed $\mathrm{F}$ values of 4,707,805 with probability values (sig.) $=0.000$. Moreover, if this value is $<0.05$, it means that simultaneously, the variables studied and involved in the model, influences the pattern of urban activity and the value of coefficients obtained as sig. $<0.05$ include variable space structure and pattern as well as activity system with their respective values, encompassing space 
J. Eng. Applied Sci., 15 (6): 1273-1288, 2020

Table 7: Effect of urban agglomeration on formation of social area structures model summary

\begin{tabular}{|c|c|c|c|c|c|c|c|c|c|}
\hline \multirow[b]{2}{*}{ Models } & \multirow[b]{2}{*}{$\mathrm{R}$} & \multirow[b]{2}{*}{$\mathrm{R}^{2}$} & \multirow[b]{2}{*}{ Adjusted $\mathrm{R}^{2}$} & \multirow[b]{2}{*}{ SE of the estimate } & \multicolumn{5}{|c|}{ Change statistics } \\
\hline & & & & & $\mathrm{R}^{2}$ change & F change & df1 & $\mathrm{df} 2$ & Sig. F change \\
\hline 1 & $1.000^{\mathrm{a}}$ & 1.000 & 1.000 & 0.181 & 1.000 & 4707.805 & 13 & 16 & 0.000 \\
\hline \multicolumn{10}{|c|}{$\begin{array}{l}\text { Predictors: (Constant), social status, social interaction, economic productivity, space structure, social adaptation, availability of residential facilities, } \\
\text { economic relations, city service access, social stratification, social relations, land tenure, activity system, space pattern }\end{array}$} \\
\hline \multicolumn{10}{|c|}{ Table 8: Effect of urban agglomeration on formation of social area structures model summary ANOVA ${ }^{a}$} \\
\hline Regressi & & 2014 & 840 & 13 & 154.988 & \multicolumn{3}{|c|}{4707.805} & \multirow{3}{*}{$\frac{\text { Sig. }}{0.000^{\mathrm{b}}}$} \\
\hline Residual & & 0.527 & & 16 & 0.033 & & & & \\
\hline Total & & 2015 & 367 & 29 & & & & & \\
\hline \multicolumn{10}{|c|}{$\begin{array}{l}\text { a. Dependent variable: urban activity pattern; }{ }^{\text {b }} \text { Predictors: (Constant), social status, social interaction, economic productivity, space structure, social } \\
\text { adaptation, availability of residential facilities, economic relations, city service access, social stratification, social relations, land tenure, activity system, } \\
\text { space pattern }\end{array}$} \\
\hline & & & \multicolumn{2}{|c|}{ Unstandardized coefficients } & \multicolumn{3}{|c|}{ Standardized coefficients } & & \\
\hline \multicolumn{3}{|l|}{ Models } & B & SE & Beta & \multicolumn{3}{|c|}{ t-values } & Sig. \\
\hline \multicolumn{3}{|c|}{ (Constant) } & -0.182 & 0.887 & & \multicolumn{3}{|c|}{-0.205} & 0.840 \\
\hline \multicolumn{3}{|c|}{ Space structure } & 1.016 & 0.016 & 0.574 & \multicolumn{3}{|c|}{64.123} & 0.000 \\
\hline \multicolumn{3}{|c|}{ Space pattern } & 0.984 & 0.019 & 0.465 & \multicolumn{3}{|c|}{51.758} & 0.000 \\
\hline \multicolumn{3}{|c|}{ Activity system } & -0.024 & 0.011 & -0.014 & \multicolumn{3}{|c|}{-2.153} & 0.047 \\
\hline \multicolumn{3}{|c|}{ Social relations } & -0.005 & 0.011 & -0.003 & \multicolumn{3}{|c|}{-0.499} & 0.625 \\
\hline \multicolumn{3}{|c|}{ Economic relation } & 0.026 & 0.013 & 0.013 & \multicolumn{3}{|c|}{1.980} & 0.065 \\
\hline \multicolumn{3}{|c|}{ Land tenure } & 0.000 & 0.004 & 0.001 & \multicolumn{3}{|c|}{0.119} & 0.907 \\
\hline \multicolumn{3}{|c|}{ Social adaptation } & 0.003 & 0.003 & 0.004 & & 0.738 & & 0.471 \\
\hline Social in & action & & 0.003 & 0.010 & 0.002 & & 0.283 & & 0.781 \\
\hline Economi & roductiv & & 0.002 & 0.005 & 0.003 & & 0.432 & & 0.671 \\
\hline City serv & access & & -0.002 & 0.004 & -0.003 & & -0.420 & & 0.680 \\
\hline Social st & fication & & 0.002 & 0.010 & 0.001 & & 0.158 & & 0.876 \\
\hline Availabi & of resid & ial facilities & -0.001 & 0.006 & -0.001 & & -0.245 & & 0.809 \\
\hline Social st & & & -0.002 & 0.003 & -0.004 & & -0.729 & & 0.476 \\
\hline
\end{tabular}

Dependent variable; Urban activity pattern

Table 10: Summary of complete structure path coefficient results

\begin{tabular}{|c|c|c|c|c|c|c|c|c|c|c|c|c|c|c|}
\hline \multirow{2}{*}{$\begin{array}{l}\text { Variables } \\
\text { influence }\end{array}$} & \multirow[b]{2}{*}{ Directly } & \multicolumn{12}{|c|}{ Indirect effects through variables } & \multirow{2}{*}{$\begin{array}{l}\text { Total } \\
\text { influence }\end{array}$} \\
\hline & & $\mathrm{X} 1$ & $\mathrm{X} 2$ & $\mathrm{X} 3$ & $\mathrm{X} 4$ & $\mathrm{X} 5$ & $\mathrm{X} 6$ & $\mathrm{X} 7$ & $\mathrm{X} 8$ & X9 & $\mathrm{X} 10$ & $\mathrm{X} 11$ & $\mathrm{X} 12$ & \\
\hline $\mathrm{X} 1$ to $\mathrm{Y}$ & 0.574 & - & 0.267 & 0.008 & 0.002 & 0.007 & 0.001 & 0.002 & 0.001 & 0.002 & 0.002 & 0.001 & 0.001 & 0.85 \\
\hline $\mathrm{X} 2$ toY & 0.465 & 0.267 & - & 0.007 & 0.001 & 0.006 & 0.000 & 0.002 & 0.001 & 0.001 & 0.001 & 0.000 & 0.000 & 0.74 \\
\hline $\mathrm{X} 3$ to $\mathrm{Y}$ & -0.014 & 0.008 & 0.007 & - & 0.000 & 0.000 & 0.000 & 0.000 & 0.000 & 0.000 & 0.000 & 0.000 & 0.000 & 0.03 \\
\hline $\mathrm{X} 4$ to $\mathrm{Y}$ & 0.003 & 0.002 & 0.001 & 0.000 & - & 0.000 & 0.000 & 0.000 & 0.000 & 0.000 & 0.000 & 0.000 & 0.000 & 0.01 \\
\hline $\mathrm{X} 5$ to $\mathrm{Y}$ & 0.013 & 0.007 & 0.006 & 0.000 & 0.000 & - & 0.000 & 0.000 & 0.000 & 0.000 & 0.000 & 0.000 & 0.000 & 0.03 \\
\hline $\mathrm{X} 6$ to $\mathrm{Y}$ & 0.001 & 0.001 & 0.000 & 0.000 & 0.000 & 0.000 & - & 0.000 & 0.000 & 0.000 & 0.000 & 0.000 & 0.000 & 0.00 \\
\hline $\mathrm{X} 7$ to $\mathrm{Y}$ & 0.004 & 0.002 & 0.002 & 0.000 & 0.000 & 0.000 & 0.000 & - & 0.000 & 0.000 & 0.000 & 0.000 & 0.000 & 0.01 \\
\hline $\mathrm{X} 8$ to $\mathrm{Y}$ & 0.002 & 0.001 & 0.001 & 0.000 & 0.000 & 0.000 & 0.000 & 0.000 & & 0.000 & 0.000 & 0.000 & 0.000 & 0.00 \\
\hline $\mathrm{X} 9$ to $\mathrm{Y}$ & 0.003 & 0.002 & 0.001 & 0.000 & 0.000 & 0.000 & 0.000 & 0.000 & 0.000 & - & 0.000 & 0.000 & 0.000 & 0.01 \\
\hline $\mathrm{X} 10$ to $\mathrm{Y}$ & -0.003 & 0.002 & 0.001 & 0.000 & 0.000 & 0.000 & 0.000 & 0.000 & 0.000 & 0.000 & - & 0.000 & 0.000 & 0.01 \\
\hline $\mathrm{X} 11 \mathrm{t}$ oY & 0.001 & 0.001 & 0.000 & 0.000 & 0.000 & 0.000 & 0.000 & 0.000 & 0.000 & 0.000 & 0.000 & - & 0.000 & 0.00 \\
\hline $\mathrm{X} 12$ to $\mathrm{Y}$ & -0.001 & 0.001 & 0.000 & 0.000 & 0.000 & 0.000 & 0.000 & 0.000 & 0.000 & 0.000 & 0.000 & 0.000 & 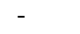 & 0.00 \\
\hline $\mathrm{X} 13$ to $\mathrm{Y}$ & -0.004 & 0.002 & 0.002 & 0.000 & 0.000 & 0.000 & 0.000 & 0.000 & 0.000 & 0.000 & 0.000 & 0.000 & 0.000 & 0.01 \\
\hline
\end{tabular}

structure $(\mathrm{X} 1)=0.000$, spatial pattern $(\mathrm{X} 2)=0.000$ and system activity $(\mathrm{X} 3)=0.047$. This means that the variable significantly affects the pattern of urban activity in the studied region. Conceptually, based on the assessment of the effects of urban activity patterns on the formation of social territorial structures, economic growth, spatial integration and urban agglomeration in municipal suburbs confirms changes in spatial structure and patterns as well as the integration of surrounding areas and changes in social adaptation between migrants and local communities. This further led to the modification of communal formation, towards that of the Mamminasata Metropolitan structure Table 4-10.

\section{CONCLUSION}

Based on the results obtained from the discussion, the following conclusions were derived. The tendency of developing Mamminasata Metropolitan suburbs towards economic growth is characterized by the direct influence 
of significant spatial use changes on integration and urban agglomeration. Therefore, the elevating intensity of development affects the integration of the studied system including the surrounding rural areas which has also triggered an increase in population, augmented economic productivity, morphological changes and typology of suburbs. Conversely, the improved pattern of urban activity cause changes in spatial structure and patterns, impacts on inequality of land tenure as well as the differences recorded in adaptation between migrants and local communities which begin with alterations in communal interaction and adaptation and also changes in social formation, towards the creation of regional suburb structures in Mamminasata Metropolitan.

The economic growth observed in the studied area has a positive contribution to the development of business centers, large-scale settlements, services, offices, education and socio-economic activities. Hence, developing centers of fiscal interests have a direct influence on its development in formal urban areas. Moreover, its coexistence with the official economy of these areas causes municipal sprawl to be characterized by the complexity of spatial use. However, in-formal events, development was due to the existence of local communities in response to a stimulus for environmental change which also directly influences transportation and movement systems within Mamminasata Metropolitan suburbs.

Urban agglomerations occurring parallel to spatial integration causes an increase in the pattern of developmental activities and the subsequent integration of urban systems. Therefore, changes in spatial use and its amalgamation impacts on the attributes, morphology and typology observed, towards inequality in land tenure. Furthermore, modification of spatial structures and patterns, characterized by elevated land values and prices lead to differentiation of business deeds between migrants and local communities.

\section{ACKNOWLEDGMENT}

The research team appreciate the reviewers for providing valuable and constructive input to this study. This research was funded by the Ministry of Education and Culture of the Republic of Indonesia, through a Grant for Higher Education Research Funds Assistance Program.

\section{REFERENCES}

Acolin, A., M.C. Hoek-Smit and C.M. Eloy, 2019. High delinquency rates in Brazil's Minha Casa Minha Vida housing program: Possible causes and necessary reforms. J. Habitat Intl., 83: 99-110.
Ahmadzai, F., K.M.L. Rao and S. Ulfat, 2019. Assessment and modelling of urban road networks using Integrated Graph of Natural Road Network (a GIS-based approach). J. Urban Manage., 8: 109-125.

Azhdari, A., M.A. Sasani and A. Soltani, 2018. Exploring the relationship between spatial driving forces of urban expansion and socioeconomic segregation: The case of Shiraz. Habitat Int., 81: 33-44.

Balogh, A., P. Bajmocy and Z. Ilcsikne-Makra, 2018. Social and ethnic segregation amongst the smallest Hungarian villages. Geog. Pannonica, 22: 208-218.

Brunetta, G., R. Monaco, E. Salizzoni and F. Salvarani, 2018. Integrating landscape in regional development: A multidisciplinary approach to evaluation in Trentino planning policies, Italy. Land Policy, 77: 613-626.

Buchori, I., A. Sugiri, M. Maryono, A. Pramitasari and I.T.D. Pamungkas, 2017. Theorizing spatial dynamics of metropolitan regions: A preliminary study in Java and Madura Islands, Indonesia. Sustainable Cities Soc., 35: 468-482.

Creswell, J.W., 2016. [Research Design: Qualitative, Quantitative and Mixed Method Approaches]. Pustaka Pelajar, Yogyakarta, Indonesia, (In Indonesian).

Dadashpoor, H., P. Azizi and M. Moghadasi, 2019. Analyzing spatial patterns, driving forces and predicting future growth scenarios for supporting sustainable urban growth: Evidence from Tabriz metropolitan area, Iran. Sustainable Cities Soc., 47: 101502-101502.

Denzin, N.K. and Y.S. Lincoln, 2009. Handbook of Qualitative Research. Penerbit Pustaka Pelajar, Indonesia, pages: 495.

Forster, T., A.E. Kentikelenis, B. Reinsberg, T.H. Stubbs and L.P. King, 2019. How structural adjustment programs affect inequality: A disaggregated analysis of IMF conditionality, 1980-2014. Social Sci. Res., 80: 83-113.

Hamma, W. and A.I. Petrisor, 2018. Urbanization and risks: Case of Bejaia city in Algeria. Hum. Geographies, 12: 97-114.

Hernantes, J., P. Marana, R. Gimenez, J.M. Sarriegi and L. Labaka, 2019. Towards resilient cities: A maturity model for operationalizing resilience. Cities, 84: 96-103.

Huang, W., S. Xu, Y. Yan and A. Zipf, 2019. An exploration of the interaction between urban human activities and daily traffic conditions: A case study of Toronto, Canada. Cities, 84: 8-22.

Kovacs, Z., Z.J. Farkas, T. Egedy, A.C. Kondor and B. Szabo et al., 2019. Urban sprawl and land conversion in post-socialist cities: The case of metropolitan Budapest. Cities, 92: 71-81. 
Kowalczyka, C., J. Kil and K. Kurowska, 2019. Dynamics of development of the largest cities-Evidence from Poland. Cities, 89: 26-34.

Kristof, A., 2018. The impact of suburbanization on social differentiation in Hungary: A case study of the Miskolc agglomeration. Geog. Pannonica, 22: 176-188.

Lalehpour, M., 2016. Recognition of management structure and spatial planning in Tehran metropolitan area. J. Urban Manage., 5: 3-15.

Lang, W., T. Chen, E.H. Chan, E.H. Yung and T.C. Lee, 2019. Understanding livable dense urban form for shaping the landscape of community facilities in Hong Kong using fine-scale measurements. Cities, 84: 34-45.

Lu, X.H. and S.G. Ke, 2018. Evaluating the effectiveness of sustainable urban land use in China from the perspective of sustainable urbanization. Habitat Int., 77: 90-98.

Lukic, V. and M.N. Stoilkovic, 2017. Interrelation of spatial disparities in development and migration patterns in transition economy: Serbia-Case study. Hum. Geographies, 11: 65-76.

Ma, G. and E.T. Hofmann, 2019. Immigration and environment in the US: A spatial study of air quality. Social Sci. J., 56: 94-106.

Masoumi, H.E., M. Hosseini and A.A. Gouda, 2018. Drivers of urban sprawl in two large middle-eastern countries: Literature on Iran and Egypt. Hum. Geographies, 12: 55-79.

Matlovic, R., R. Klamar, J. Kozon, M. Ivanova and M. Michalko, 2018. Spatial polarity and spatial polarization in the context of supranational and national scales: Regions of Visegrad countries after their accession to the EU. Bull. Geogr. Socio Econ. Ser., 41: 59-78.

Mohamed, A.A., R.M. Elebrashi and M. Saad, 2019. A test of the functional theory of human values in Egypt. Social Sci. J., 56: 118-126.

Mualam, N., E. Salinger and D. Max, 2019. Increasing the urban mix through vertical allocations: Public floorspace in mixed use Development. Cities, 87: 131-141.

Nakamura, D., 2013. Spatial policy for a competitive regional system: Economic and social infrastructure elements. J. Urban Manage., 2: 103-112.

Nengroo, Z.A., M.S. Bhat and N.A. Kuchay, 2017. Measuring urban sprawl of Srinagar city, Jammu and Kashmir, India. J. Urban Manage., 6: 45-55.

Ngoran, S.D. and X. Xue, 2015. Addressing urban sprawl in Douala, Cameroon: Lessons from Xiamen integrated coastal management. J. Urban Manage., 4: 53-72.

Olajide, O.A., M.E. Agunbiade and H.B. Bishi, 2018. The realities of Lagos urban development vision on livelihoods of the urban poor. J. Urban Manage., 7: 21-31.
Oyinlola, M., T. Whitehead, A. Abuzeinab, A. Adefila and Y. Akinola et al., 2018. Bottle house: A case study of transdisciplinary research for tackling global challenges. Habitat Int., 79: 18-29.

Patra, S., S. Sahoo, P. Mishra and S.C. Mahapatra, 2018. Impacts of urbanization on land use/cover changes and its probable implications on local climate and groundwater level. J. Urban Manage., 7: 70-84.

Qiu, R., W. Xu and J. Zhang, 2015. The transformation of urban industrial land use: A quantitative method. J. Urban Manage., 4: 40-52.

Qu, Y. and H. Long, 2018. The economic and environmental effects of land use transitions under rapid urbanization and the implications for land use management. Habitat Int., 82: 113-121.

Rahman, M.A.U., 2016. Urban sustainability vthrough strategic planning: A case of metropolitan planning in Khulna city, Bangladesh. J. Urban Manage., 5: 16-22.

Rasoul, F., 2017. Managing service potentiality of small urban centers case study: City of Sardasht, South East of Iran. J. Urban Manage., 6: 3-18.

Rochovska, A. and J. Rusnakova, 2018. Poverty, segregation and social exclusion of Roma communities in slovakia. Bull. Geogr. Socio Econ. Ser., 42: 195-212.

Soyinka, O., K.W.M. Siu, T. Lawanson and O. Adeniji, 2016. Assessing smart infrastructure for sustainable urban development in the Lagos metropolis. J. Urban Manage., 5: 52-64.

Sulemana, I. and D. Kpienbaareh, 2018. An empirical examination of the relationship between income inequality and corruption in Africa. Econ. Anal. Policy, 60: 27-42.

Sulemana, I., E. Nketiah-Amponsah, E.A. Codjoe and J.A.N. Andoh, 2019. Urbanization and income inequality in Sub-Saharan Africa. Sustainable Cities Soc., 48: 1-4.

Surya, B. and H. Saleh, 2018. Transformation of metropolitan suburban area (a study on new town development in Moncongloe-Pattalassang metropolitan maminasata). IOP. Conf. Ser. Earth. Environ. Sci., Vol. 202, 10.1088/17551315/202/1/012027

Surya, B., 2015. Optimization of function and role of traditional markets in urban development system of Ketapang city (A case study: Range Sentap Market, Delta Pawan Subdistrict, Ketapang city). World Applied Sci. J., 33: 1457-1471.

Surya, B., 2015c. Spatial interaction pattern and the process of city activity formation system (case study, Ternate, Tidore Archipelago and Sofifi city of North of Maluku). Res. J. Appl. Sci., 10: 880-892.

Surya, B., 2015b. The dynamics of spatial structure and spatial pattern changes at the fringe area of Makassar City. Indonesian J. Geogr., 47: 11-19. 
Surya, B., 2016a. Change phenomena of spatial physical in the dynamics of development in urban fringe area. Indonesian J. Geography, 48: 118-134.

Surya, B., 2016b. The processes analysis of urbanization, spatial articulation, social change and social capital difference in the dynamics of new town development in the fringe area of Makassar City (case study: In Metro Tanjung Bunga Area, Makassar City). Proc.-Social Behav. Sci., 227: 216-231.

Surya, B., H. Saleh and H. Remmang, 2018b. Economic gentrification and socio-cultural transformation metropolitan suburban of Mamminasata. J. Eng. Appl. Sci., 13: 6072-6084.

Surya, B., M. Ruslan and H. Abubakar, 2018a. Inequility of space reproduction control and Urban slum area Management Sustainability (case study: Slum area of Buloa urban village in Makassar City). J. Eng. Appl. Sci., 13: 6033-6042.

Suzuki, S. and P. Nijkamp, 2018. Winners in the urban champions league-A performance assessment of Japanese cities by means of dynamic and super-efficient DEA. J. Urban Manage., 7: 6-20.

Tan, R., Y. Liu, Y. Liu, Q. He, L. Ming and S. Tang, 2014. Urban growth and its determinants across the Wuhan urban agglomeration, central China. Habitat Int., 44: 268-281.

Wang, L., B. Pijanowski, W. Yang, R. Zhai, H. Omrani and $\mathrm{K}$. Li, 2018. Predicting multiple land use transitions under rapid urbanization and implications for land management and urban planning: The case of Zhanggong District in central China. Habitat Int., 82: $48-61$.
Wang, X. and J. Tomaney, 2019. Zhengzhou-political economy of an emerging Chinese megacity. Cities, 84: 104-111.

Yang, Y. and N. Hu, 2019. The spatial and temporal evolution of coordinated ecological and socioeconomic development in the provinces along the Silk Road Economic Belt in China. Sustainable Cities Soc., Vol. 47,

Ye, C., J. Zhu, S. Li, S. Yang and M. Chen, 2019. Assessment and analysis of regional economic collaborative development within an Urban agglomeration: Yangtze River Delta as a case study. J. Habitat Intl., 83: 20-29.

Zeng, C., Y. Song, D. Cai, P. Hu, H. Cui, J. Yang and H. Zhang, 2019. Exploration on the spatial spillover effect of infrastructure network on urbanization: A case study in Wuhan urban agglomeration. Sustainable Cities Soc., Vol. 47, 10.1016/j.scs.2019.101476

Zhang, C., C. Miao, W. Zhang and X. Chen, 2018. Spatiotemporal patterns of urban sprawl and its relationship with economic development in China during 1990-2010. Habitat Int., 79: 51-60.

Zhang, Y., Y. Fu, X. Kong and F. Zhang, 2019. Prefecture-level city shrinkage on the regional dimension in China: Spatiotemporal change and internal relations. Sustainable Cities Soc., Vol. 47, 10.1016/j.scs.2019.101490

Zhong, T., Z. Qian, X. Huang, Y. Zhao, Y. Zhou and Z. Zhao, 2018. Impact of the top-down quota-oriented farmland preservation planning on the change of urban land-use intensity in China. Habitat Int., 77: 71-79. 